\title{
Population Stress Reactions in North-East Hungary during the Pandemic
}

\author{
Andrea Rucska \\ Faculty of Health, University of Miskolc, Miskolc, Hungary \\ Csilla Lakatos \\ Faculty of Health, University of Miskolc, Miskolc, Hungary
}

\section{Abstract}

Emergency caused by the SARS-CoV-2 has provoked several difficulties in daily life. On the other hand, it provided an opportunity to produce new attitudes toward our life and community, but also forced us to face our vulnerabilities. Outbreak of the SARS-CoV-2 highlighted that despite our vulnerability, we can manage this crisis, by being able to influence our stress reaction as well as our fears and emotions about the pandemic. Faculty of Healthcare of the University of Miskolc is training such professionals, whose priority task is to preserve the mental health of individuals and communities, reduce stress reactions, increase the available information on the subject, and help the community to adapt adequately to unexpected difficulties, like a pandemic situation. In the present study, we examined the mental state of the population of Northeastern Hungary in the second wave to adapt the abovedescribed education to the ongoing changes caused by the pandemic. During the research, we applied an online questionnaire, that included the Hungarian version of the 10-item Perceived Stress Scale-, the Adult Hope Scale-, the WHO Well-Being, and the Buss Perry aggression questionnaire. Most participants $(n=528)$ live in small towns or villages and their average age is $39.4 \pm 13.1$. The aggression level of responders did not reach the threshold, but the level of verbal aggression exceeded it. The participants were more stressed, but they thought they could handle their problems. Consequently, the pandemic harms the mental state and health of the population, therefore the presence of health professionals is needed.

Keywords: pandemic, stress, aggression, subjective well-being, online questionnaire

\section{Introduction}

The new coronavirus (SARS-CoV-2) occurred in the Chinese Wuhan in the end of 2019 has reached Europe and Hungary in the spring of 2020. The pandemic has upset our whole previous lifestyle and it has become a strong stress resource. Over the fear from 
the viral infection, our daily life management has completely changed, just as our methods for contacting, learning or work. The population has suddenly had to create several new habits and coping methods. Besides the unpleasantness of the loss of the common behavioural routines, numerous people have to face with serious existential difficulties as well. Life could be partly rearranged after the first wave, but the second wave of the pandemic started in the autumn of 2020.

By our research, we would like to contribute to the more precise understanding of the correlations of psychological phenomena experienced in the second wave of the pandemic, such as perceived stress, aggression, psychological well-being and hope. Our research aimed the assessment of the mental health of the population living in one of the seven Hungarian statistical regions, the North-East Hungarian region to, based on the results, help professionals working on health and social fields to react appropriately to the needs developed in this current situation.

\section{Literature Rewiew}

The World Health Organization (WHO) announced that the coronavirus epidemic has reached the pandemic size on 11 March 2020.

In Hungary, after the first wave of the coronavirus epidemic, the second one became noticeable in the autumn of 2020. On 09 November, the new coronavirus infection (COVID-19) was detected in 5162 Hungarian citizens, thus the number of detected infected people rose to 114778 in Hungary, and the number of deaths also increased to 2 493. At this time, the number of active infected people was $86134 ; 6061$ of them were hospitalized, and 415 of them were on respirators. By the constant increase of the newly registered case numbers, the government recorded the law about the protection against the second wave of the coronavirus pandemic in a decree on 10 November. By the announcement of the emergency, serious limitations have been introduced such as curfew between 8 p.m. and 5 a.m., changing to on-line education in high schools and universities, compulsory face mask wearing in closed areas and in public areas in settlements counting more than 10000 persons as well. A general ban on organizing events has been introduced, assemblies have become forbidden. The number of participants on personal and family events became limited; hotels could not receive tourists, accommodation was available only for business, economic or educational purposes. Besides the police, the army also got authorization for monitoring the compliance with the epidemiological rules, and great fines were placed in perspective in case of violation. The second wave of the epidemic reached its peak in the beginning of December when the daily number of new infections reached 6 697, and the number of deaths was 193. However, the government announced the tightening in November 2020 for 30 days, these have been prolonged more times since then, and they are still in force at the time of writing this study (in February 2021), and there are no prospects for their mitigation.

In the last year, several studies and statements have dealt with the effects of COVID19 on the physical (Cao \& Li, 2020, Lvov et al., 2020) and mental well-being (Brooks 
et al., 2020, Pfefferbaum \& North, 2020, Serafini et al., 2020). The research results have proved it in several cases that the epidemic can be linked to the worsening of the symptoms of depression, anxiety and perceived stress (Cao et al., 2020, Xiong et al., 2020, Li et al., 2021). Social distance, isolation, the fear from the infection and the stigma associated with it, existential uncertainty, the lack of information or its contradictions are associated with such negative psychiatric symptoms as frustration and boredom, post-traumatic stress reactions, panic symptoms, anger and irritability, low self-esteem, and the feeling of loneliness and helplessness (Brooks et al.2020, Hossain et al., 2020). The listed negative internal conditions significantly decrease the level of our mental well-being (Serafini et al., 2020).

According to Lazarus's and Folkman's definition (1984), the psychological condition of stress develops when a person meets a situation which, based on his own judgement, exceeds his available resources. So, the way a person views a certain situation is of central importance. Because the processes start on more planes due to the stressors (events causing stress): on emotional, cognitive, somatic and behavioural level. The creators of cognitive stress theories think that cognitive evaluation has a determining role in the development of the stress reaction, so the stress level can be influenced by its change. Several individual differences can be observed in this mechanism, such as the sensibility for stimuli, but earlier experience and genetic factors also influence the evaluation (Ursin \& Eriksen, 2004). The reaction for stress is also influenced by predictability and controllability which are the aspects of cognitive evaluation. If the person thinks that he has only a little or no control above a certain event, and he is unable to judge when it happens, his body will react with a more intensive stress reaction (Kopp, 2011). At the same time, the reality of the evaluation has an important role in the process; if the qualification loses from its reality value due to a factor (for example earlier experience), different cognitive distortions began to work because of which we feel the stress situation to be more negative (Stauder et al, 2010).

The pathogenic effect of stress can be interpreted in a complex, circular causal system in which biological, psychological and social factors play role as well. The fact whether stress will cause a somatic or mental illness greatly depends on the type, duration and severity of stress (Agid et al, 2000). Mild but long-lasting stress has an essential role in the development of somatic and mental disorders, and these affect the subjective health status (Stauder \& Konkoly, 2006). But a sequence of events alone is not pathogenic, it becomes so because of the person's reaction for stress. So, it is important to consider the individual differences in the perception of stress; the way how the affected person interprets the stress situation (Felisa et al, 2020).

According to Berkowitz (1989), any negative feelings may cause aggression. In the model, pain, fear and irritation can also be found besides frustration and anger among the negative feelings causing aggression. Life situations caused by the COVID-19 pandemic strengthen the intensity of negative feelings and thus, they cause aggression. On the one hand, the uncertainty coming from the situation (the course of 
the disease, the unpredictability of the end of the virus situation, existential threat) increases the level of stress in its own, and long-lasting stress depletes the personal resources which inhibit aggressive behaviour. On the other hand, the long-lasting limitation of free movement, earlier activities and social relationships develops frustration, and frustration is proved to be the focal point of interpersonal aggression (Krahé, 2013). Mazza et al draw the attention to the worsening of domestic abuse due to the isolation and the increase of time spent at home caused by the pandemic, especially to the danger of relationship aggression. However, relationship stress is not separated within the family, it seriously affects children as well. By now, several studies have proved that during the pandemic, parental stress may be accompanied by hostility or neglect towards children, and this further aggravates the adolescents' mental problems associated with the pandemic situation (Brown et al., 2020, Cluver et al., 2020, Spinelli et al., 2020). At the same time, examination results obtained from a Hungarian sample suggest that resilience has been proved to be a protecting factor regarding perceived stress during the pandemic in terms of both parents and children (Csíkos et al, 2020). So, mapping the factors that could moderate aggression associated with stress may be important in this long-lasting, burdening period.

\section{Methods}

\section{Participants}

Data recording of this current cross-sectional research was performed in the end of November and in the beginning of December in 2020, the questionnaire was filled by 528 persons. Only age was marked as a criterion to participate in the on-line survey research: only those respondents could be involved who have passed the age of 18 . Educational level, relationship status or the settlement type were not criteria in the research. Before filling the questionnaire, the participants received written information about the aim of the research. Although the results are not representative, the sample gives an informative picture about the mental characteristics of people living in North-East Hungary during the second wave of the pandemic.

\section{Measures}

During data recording, we queried labour market status, relationship status and the size of the residential settlement besides the socio-demographic data (gender, age, education). There was one question about the respondent's evaluation regarding his/her own health status and another about religiousness. There were further questions about COVID-19 infection or its suspicion in terms of the person's own and immediate environment, the severity of the perceived symptoms and the form of the necessary health care.

The Ten-item Perceived Stress Scale (PSS-10) was used to measure the subjects' perception of stress (Cohen et al., 1983). The questionnaire consists of 10 items which should be scored on a 5-point Likert-scale (0-4). At the certain items, the higher scores 
indicate the higher frequency of stress situations and more successful coping. The internal consistency of the Hungarian version of the questionnaire is quite good (Cronbach's alpha=0.85) (Stauder et al, 2006).

General well-being was assessed by the five-item version of the WHO Well-Being Index (Bech et al 1996), a widely used questionnaire that measures general psychological well-being (positive mood, relaxation, activity, sleep quality) on a 4-point Likert scale. The Hungarian version had good internal consistency (Cronbach's alpha = 0.85) (Susánszky et al., 2006).

The Aggression questionnaire (Buss \& Perry, 1992) uses 29 variables to map the trait aggression of the personality's four different fields: physical and verbal aggression, anger as the affective component of aggression and hostility as the cognitive component of aggression. The variables could be evaluated on a ' 1 to 5 ' Likert scale. High score refers to a higher level of aggressiveness (Gerevics \& Bácskai, 2012).

To measure the construction of hope, we used the Hungarian version of Hope Scale (Synder et al, 1991) (AHS-H) which had 12 items to measure general (global) hope on an eight-point Likert scale (1-8). The internal consistency of the Hungarian version of the questionnaire is excellent (Cronbach's alpha=0.88) (Martos et al, 2014).

We used SPSS 20.0 program for data analysis, and over descriptive statistical methods, we used correlation analysis, T-probe and chi-squared test.

\section{Results}

\section{Demographics}

The average age of the 528 persons involved in the research is $39.4 \pm 13.1$ years. Women's responding activity was much higher (89.4\%) than men's $(10.6 \%)$.

$44.7 \%$ of the respondents live in cities, $28.8 \%$ in towns and $26.1 \%$ live in villages. Most of them has higher education level (59.3\%), 28.2\% has high school final graduation, $7.3 \%$ has technical qualification, $20.7 \%$ are workmen and $2.5 \%$ has basic education. Most of the respondents has a regular job (62.1\%), the rate of students $(15.3 \%)$ and women raising infants $(11.5 \%)$ is high. Pensioners $(7.5 \%)$ and unemployed people $(2.5 \%)$ also took part in the research. $45 \%$ of the unemployed people have lost their jobs more than a year ago, $27.3 \%$ in the last year, and also $27.3 \%$ has become unemployed in the last 3 months. The majority has intellectual jobs (31.9\%), 23.5\% has other kind of intellectual job, and 23.7\% works in health care. Most of them work in a subordinate position (69\%), but $12.3 \%$ is self-employed, $10.9 \%$ is a middle manager, $3.9 \%$ is the rate of group leaders, and also $3.9 \%$ works as a senior manager.

$16.7 \%$ of the asked people had underwent the COVID-19 infection, $37.9 \%$ of them were unsure about undergoing it. Most of the people having been infected (50.4\%) had mild symptoms, while $47.8 \%$ suffered from medium strength symptoms. When 
we asked about the wider environment, they reported essentially more infections: the infection could have been detected in all the respondents' households. $22.7 \%$ of those living in one household had at least one infected family member and $77.3 \%$ had more than one infected family members. The severity of the course of the infection was different: $32 \%$ judged it very mild, $60.9 \%$ said it was medium, $3.1 \%$ of them needed hospitalization, and the course of the infection was fatal in the environment of $3.5 \%$ of the respondents. When examining a much wider environment, we met greater dispersion: $17.5 \%$ said that there were not infected people among his/her wider family members or friends, one infected person could be detected in case of $22.4 \%$, and more relatives or friends were COVID-19 infected in the case of $60.1 \%$ of the respondents. In this group, mild symptoms were reported only in $21.3 \%$, medium strength symptoms could be detected in 53.5\%, 9.8\% received hospital treatment, $2.1 \%$ received intensive care and $13.1 \%$ of the cases were fatal.

\section{Perceived stress and demographics}

The global indicator of perceived stress in the examined sample is $17.61 \pm 4$.6. Its minimal value is 3 , the maximum is 40 . There is no significant difference in the case of genders $(p=0.76)$, but men suffer from a bit more stress than women (Table 1$)$.

stress total score

\begin{tabular}{|l|l|}
\hline gender & mean \\
\hline male & 17.8571 \\
female & 17.6547 \\
Total & 17.6761 \\
\hline
\end{tabular}

Table 1: Perceived stress score in terms of genders

A significant difference can be experienced examining in terms of age $(p=0.004)$; the older a person is, the more the stress index increases. Although, there is no significant difference in terms of the residence, the size of the settlement shows a trend level correlation with the stress level of people living there in such a way that the stress index of people living in smaller settlements is lower than people's living in bigger settlements (Table 2).

stress total score

\begin{tabular}{|l|l|}
\hline Residence & Mean \\
\hline city & 17.825 \\
town & 17.776 \\
village & 17.579 \\
\hline
\end{tabular}

Table 2: Perceived stress score in terms of residence

${ }_{1}^{1}$ Maximum score of perceived stress: 40 points. 
Stress index was found to be higher, however not significantly ( $\mathrm{p}=0.053)$, in case of respondents who had undergone the infection or there had been a COVID-infected person in the family and in the wider environment.

\section{Aggression and demographics}

The participants' aggregated aggression index is $64.3 \pm 16.2^{1}$, which does not reach the threshold index.

A significant difference can be detected in terms of genders $(p=0.008)$ and age $(p=0.0002)$, the aggression index of younger men is higher than women's index (Table $3)$.

aggregated aggression

\begin{tabular}{|l|l|}
\hline gender & Mean \\
\hline male & 69.7500 \\
female & 63.6610 \\
\hline
\end{tabular}

Table 3: Aggregated aggression score in terms of genders

Examining the residence, it can be observed that there is a significant difference between the aggression index and residence $(p=0.05)$; the aggression value is the lowest in the case of people living in cities (Table 4).

total aggression

\begin{tabular}{|l|l|}
\hline Residence & Mean \\
\hline city & 61.6403 \\
town & 65.5724 \\
village & 64.5362 \\
\hline
\end{tabular}

Table 4: Aggregated aggression score in terms of residence

The aggression index of people infected by COVID-19 is also significantly higher $(\mathrm{p}=0.045)$.

Examining the different trait aggressions, it can be stated that only verbal aggression exceeds the threshold value (Table 5), but hostility had the greatest dispersion (SD: 5,94680 ).

The highest level of physical aggression could be found in towns, the index mean of people living in cities and villages was almost the same (15.5).

${ }^{1}$ The maximum score of aggression is 145 . 
The highest verbal aggression index could be found in villages (13.4), the smallest in cities (12.7).

\begin{tabular}{|c|c|c|c|c|}
\hline & $\begin{array}{l}\text { physical } \\
\text { aggression }^{1}\end{array}$ & verbal aggression ${ }^{2}$ & anger ${ }^{3}$ & hostility ${ }^{4}$ \\
\hline $\begin{array}{l}\text { Mean } \\
\text { Std. Deviation }\end{array}$ & \begin{tabular}{|l|}
15.9924 \\
5.28181 \\
\end{tabular} & $\begin{array}{l}13.2311 \\
3.71054\end{array}$ & $\begin{array}{l}16.9394 \\
4.86791\end{array}$ & $\begin{array}{l}18.1439 \\
5.94680\end{array}$ \\
\hline
\end{tabular}

Table 5:Scores and dispersions of different trait aggressions

Fury is a violent standby state which could be experienced in the case of the feeling of growing anger. In the case of fury, the person explodes negative feelings even for minimal provocation, reacts with roughness, and behaves angrily, rudely. In fury, the high level of adrenaline results in that the person becomes able to commit things which seem to be physically impossible in a normal, trivial case. Although, the value of fury does not reach the threshold value in this examination, but it is strongly close to it. The index of fury is the lowest in people living in cities (16.1), people living in villages come next (16.7) and it is the highest in towns (17.41) which is almost on the threshold value.

Hostility is the set of negative attitudes about people, so it is malicious, hostile and angry dissatisfaction. One of the projections of hostility is distrust during which the person supposes that he/she is contempted and hurt by others, and the environment plans something to his/her detriment. According to Kopp's research (1992), hostility is the typical attitude of the Hungarian population. According to Kopp and Prékopa (2011), the attitude of hostility has a significant health risk, because its increased occurrence increases the possibility of losing control, since in human "games" the individual basically supposes its environment to be hostile. The hostility index of the examination participants is close to the threshold value. It was the lowest in people living in cities (17.2), the population of towns is the next (18.46), and it was the highest in the case of village people (18.78).

\section{Well-being}

The WHO's General Well-being Scale provides information about people's general well-being on a basis of a two-week period in relation to the questionnaire filling. The highest the mean score is, the more typical the certain feature is (Table 6).

\begin{tabular}{|c|c|c|c|c|}
\hline $\begin{array}{l}\text { I have been } \\
\text { happy and } \\
\text { cheerful in the } \\
\text { last } 2 \text { weeks. }\end{array}$ & $\begin{array}{l}\text { I have felt } \\
\text { myself calm } \\
\text { and relaxed in } \\
\text { the last } 2 \\
\text { weeks. }\end{array}$ & $\begin{array}{l}\text { I have felt } \\
\text { myself active } \\
\text { and lively in the } \\
\text { last } 2 \text { weeks. }\end{array}$ & $\begin{array}{l}\text { When waking } \\
\text { up, I have felt } \\
\text { myself fresh } \\
\text { and lively in the } \\
\text { last } 2 \text { weeks. }\end{array}$ & $\begin{array}{l}\text { His/her days } \\
\text { have been full } \\
\text { of interesting } \\
\text { things in the } \\
\text { last } 2 \text { weeks. }\end{array}$ \\
\hline
\end{tabular}

1The threshold value of physical aggression is 22.5

2The threshold value of verbal aggression: 12.5

${ }^{3}$ Threshold value of anger: 17.5

4Threshold value of hostility: 20 


\begin{tabular}{|l|l|l|l|l|l|} 
Mean & 2.3182 & 1.9280 & 1.9735 & 1.4640 & 1.7273 \\
Std. Deviation & .82713 & .97528 & .88807 & .99077 & .93298 \\
\hline
\end{tabular}

Table 6: WHO General Well-being Scale

It can be observed on the scale that happiness and cheerfulness is typical for the respondents, they are active, calm and relaxed, but interesting activities have mostly missed from their lives. A significant difference in terms of age can be detected only in the activity sub-scale of the scale $(p=0.00003)$. The score of women belonging to the older age group is higher than the younger persons' score. In the case of wellbeing, there is no correlation in terms of the settlements ( $p=0.035)$, but people living in towns feel themselves the best, then the population of the cities comes next, and people living in villages feel themselves the worst. The condition of well-being has significantly deteriorated in case of people who had a family member infected by COVID-19 ( $\mathrm{p}=0.02)$.

\section{Hope, religion and stress}

At Hope Scale, we also examine the sub-factors of Agency and Pathways separately (Table 7). The Agency sub-factor of the questionnaire explains the person's motivation strength directed to the goals, while the Pathways part indicates the person's ability that helps him to find the ways leading to the target (Martos et al, 2014).

\begin{tabular}{|l|l|l|l|}
\hline & agency & pathways & hope \\
\hline Mean & 5.4020 & 5.5355 & 5.4688 \\
Std. Deviation & 1.85241 & 1.89828 & 1.81566 \\
\hline
\end{tabular}

Table 7: The mean scores and dispersions of the components of Hope Scale

Goals are the leaders of the human personality and behaviour which help the person to understand his/her subjective experiences. Finding the ways leading to the personal strength occurs more definitely in the sub-scale. However, the occurrence of the residence is not significant in the Hope Scale $(\mathrm{p}=0.078)$, but it occurs markedly in the Pathways sub-scale ( $p=0.057)$. Hope was highest in people living in cities (5.6) and the lowest in people living in villages (5.2). In the case of genders, no significant differences can be experienced $(p=0.4)$, but women (5.48) are a little bit more optimistic than men (5.35).

There is not any correlation ( $\mathrm{r}=0.031)$, but religion has a great role in people's optimism. Those reached the highest mean score who practised their religion regularly in a church (5.8), and those who are religious in their own way (5.6). The non-religious respondents reached a significantly lower score $(\sim 5.2)$ in this research. 
Hope is a quite essential personality trait because it usually provides motivation in seemingly hopeless situations.

\section{Discussion}

The second wave of COVID-19 pandemic hit the Hungarian population much more intensively than the first one. The number of infections increased exponentially, and mortality ratios did so. It is becoming harder and harder for the population to bear the limitations aiming curbing the pandemic, which obviously increase the symptoms of depression, anxiety and perceived stress of the population above the age of 18 in the disadvantaged region, and this is also supported by international research (Cao et al., 2020, Xiong et al., 2020, Li et al., 2021).

In our research, the scores of the perceived stress questionnaire did not exceed the critical 50\%, but they were strongly close to it, and their dispersion was also high. Men's stress reaction was obviously higher than women's, but mostly men were affected by unemployment in this period, most of them lost their jobs during this pandemic period mostly because of their lower educational level than women. Age and residence did not influence stress index essentially, but it could be obviously seen that the older age group was more stressful what was understandable since they have suffered more due to the epidemic. In terms of the residence, it can be observed that more stress reactions could be detected in bigger settlements. Social distancing, isolation, the fear from the infection and existential uncertainty caused more frustration in bigger settlements than in villages what is understandable, since people living in villages have bigger space for life than in cities.

In the case of the examination of the population's aggression level, we also experienced that the values did not reach the threshold value. Men are significantly more aggressive than women, but aggressive behaviour manifest less in case of people living in cities. There is a negative medium strength correlation $(\mathrm{r}=-0.36)$ between stress and aggression, so lower stress index goes with higher aggression level. Verbal aggression is more marked in the region, but the fury and the hostility indexes are also more strongly present that often occurs as a socio-cultural behavioural form in disadvantaged settlements and it did not manifest during the pandemic.

The "well-being" of people related to the infection somehow was significantly worse than the others' that was independent from the fact that the respondent had been infected or one of his/her relatives. Examining all scales, people having an intellectual job and living in towns feel themselves the best. The existing stress and the existing negative internal condition significantly decrease mental well-being (Serafini et al, 2020).

Hope is such a dynamic personality trait and internal power that motivates the individual for coping in seemingly hopeless life situations. People living in cities are the most optimistic, and hopelessness is more marked in people living in villages that 
is one of the possible causes of the socio-economic condition related to disadvantaged situation. Faith and religion have a great role in people's optimism and hope.

\section{Conclusion}

The results of the examination aiming the mental health assessment of the population performed in the north-east region of Hungary during the second wave of the pandemic coincide with those international and national studies which have proved COVID-19's negative effect on mental health. The correlation between the increase of the level of stress caused by the pandemic, the deterioration of well-being and the increase of the level of interpersonal aggression can be determined with high certainty among people living in the examined, socio-economically disadvantaged region. However, the level of perceived stress showed a reverse correlation with the feeling of hope and the fact of religious faith and belonging to a religious community, so with emotional coping. In the examined sample, the correlations between the mental phenomena have been proved mainly in the case of men, older people and people living in bigger settlements. Our results are essential in the case of a possible next pandemic wave for the success of prevention and intervention work, and they have practical importance for professionals working on health and social fields.

\section{References}

[1] Agid, O., Kohn, Y., \& Lerer, B. (2000). Environmental stress and psychiatric illness. Biomedicine \& Pharmacotherapy, 54(3), 135-141. https://doi.org/10.1016/s0753-3322(00)89046-0

[2] Berkowitz, L. (1989). Frustration-aggression hypothesis: Examination and reformulation. Psychological Bulletin, 106(1), 59-73. https://doi.org/10.1037/0033-2909.106.1.59

[3] Brooks, S. K., Webster, R. K., Smith, L. E., Woodland, L., Wessely, S., Greenberg, N., \& Rubin, G. J. (2020). The psychological impact of quarantine and how to reduce it: rapid review of the evidence. The Lancet, 395(10227), 912-920. https://doi.org/10.1016/s0140-6736(20)30460-8

[4] Brown, S. M., Doom, J. R., Lechuga-Peña, S., Watamura, S. E., \& Koppels, T. (2020). Stress and parenting during the global COVID-19 pandemic. Child Abuse \& Neglect, 110, 104699.

https://doi.org/10.1016/j.chiabu.2020.104699

[5] Buss, A. H., Perry, M., (1992). The Aggression Questionnaire. Journal of Personality and Social Psychology, 63(3), 452-459.

[6] Cao, W., and Li, T. (2020). COVID-19: towards understanding of pathogenesis. Cell Research 30(5),367-369. doi: 10.1038/s41422-020-03274.

[7] Cluver, L., Lachman, J. M., Sherr, L., Wessels, I., Krug, E., Rakotomalala, S., Blight, S., Hillis, S., Bachman, G., Green, O., Butchart, A., Tomlinson, M., Ward, C. L., Doubt, J., \& McDonald, K. (2020). Parenting in a time of COVID-19. The Lancet, 395(10231), e64. https://doi.org/10.1016/s0140-6736(20)30736-4 
[8] Csikós, G., Törő ,K., Rózsa, S., Hadházi, É., Kövesdi, Andrea., Földi, R. (2020). Psychological Factors in Hungarian Families under the Coronavirus Pandemic - The Effects of Resilience and Stress on the Wellbeing of Adolescents, Their Interconnections Within The Family, Icms XIII 23rd International Conference on Multidisciplinary Studies: "Resilience For Survival" Cambridge, 30-31 July 2020

[9] Cohen, S., Kamarck, T., \& Mermelstein, R. (1983). A Global Measure of Perceived Stress. Journal of Health and Social Behavior, 24(4), 385. https://doi.org/10.2307/2136404

[10] Flesia, L., Monaro, M., Mazza, C., Fietta, V., Colicino, E., Segatto, B., \& Roma, P. (2020). Predicting Perceived Stress Related to the Covid-19 Outbreak through Stable Psychological Traits and Machine Learning Models. Journal of Clinical Medicine, 9(10), 3350. https://doi.org/10.3390/jcm9103350

[11] Gerevich, J., Bácskai, E. (2012). Korszerű addiktológiai mérőmódszerek. Budapest, Semmelweis

[12] Kopp, M., Prékopa, A. Ember-környezetei játékelméleti, Magyar Tudomány, 2011, 06.05, Magyar Tudományos Akadémia, Budapest, 2011, http://www.matud.iif.hu/2011/06/05.htm, 08/06/. 2016.

[13] Kopp, M., Skrabski, Á. (1992). Magyar lelki állapot. Végeken Kiadó. Budapest

[14] Krahé, B. (2013). The Social Psychology of Aggression: 2nd Edition (Social Psychology: A Modular Course) (2nd ed.). Psychology Press.

[15] Lazarus, R. S., Folkman, S. (1984). Stress, Appraisal, and Coping. New York: Springer.

[16] Lazarus, R.S. (1974). Psychological stress and coping in adaptation and illness. Int. J. Psychiatry Med. 5: 321-333.

[17] Li, H., Hafeez, H. Zaheer, M. A. (2021). COVID-19 and Pretentious Psychological Well-Being of Students: A Threat to Educational Sustainability. Front. Psychol. 11:628003. doi: 10.3389/fpsyg.2020.628003

[18] Lvov, D.K., Alkhovsky, S.V., Kolobukhina, L.V., and Burtseva, E.I. (2020). Etiology of epidemic outbreaks COVID-19 on Wuhan, Hubei province, Chinese People Republic associated with 2019-nCoV (Nidovirales, Coronaviridae, Coronavirinae, Betacoronavirus, Subgenus Sarbecovirus): lessons of SARS-CoV outbreak. Vopr Virusol 65(1), 6-15. https://doi.org/10.36233/0507-4088-2020-65-1-6-15.

[19] Mazza, M., Marano, G., Lai, C., Janiri, L., \& Sani, G. (2020). Danger in danger: Interpersonal violence during COVID-19 quarantine. Psychiatry Research, 289, 113046. https://doi.org/10.1016/j.psychres.2020.113046

[20] Martos, T., Lakatos, Cs., Tóth-Vajna, R. (2014). A Remény Skála magyar változatának (AHS-H) pszichometriai jellemzői. Mentálhigiéné és Pszichoszomatika, 15(3), 187-202. https://doi.org/10.1556/Mental.15.2014.3.2 
[21] Pfefferbaum, B., North, C. S. (2020). Mental Health and the Covid-19 Pandemic. New England Journal of Medicine, 383(6), 510-512. https://doi.org/10.1056/nejmp2008017

[22] Serafini, G., Parmigiani, B., Amerio, A., Aguglia, A., Sher, L., \& Amore, M. (2020). The psychological impact of COVID-19 on the mental health in the general population. QJM: An International Journal of Medicine, 113(8), 531537. https://doi.org/10.1093/qjmed/hcaa201

[23] Spinelli, M., Lionetti, F., Setti, A., \& Fasolo, M. (2020). Parenting Stress During the COVID-19 Outbreak: Socioeconomic and Environmental Risk Factors and Implications for Children Emotion Regulation. Family Process. https://doi.org/10.1111/famp.12601

[24] Stauder, A., Konkoly, T. B. (2006). Az Észlelt Stressz Kérdőív (PSS) Magyar Verziójának Jellemzői. Mentálhigiéné és Pszichoszomatika 7(3), 203-216. https://doi.org/10.1556/Ment·l.7.2006.3.4

[25] Stauder, A., Konkolÿ Thege, B., Kovács, M. E., Balog, P., Williams, V. P., \& Williams, R. B. (2009). Worldwide Stress: Different Problems, Similar Solutions? Cultural Adaptation and Evaluation of a Standardized Stress Management Program in Hungary. International Journal of Behavioral Medicine, 17(1), 25-32. https://doi.org/10.1007/s12529-009-9054-4

[26] Susánszky, É., Konkoly, T. B., Stauder, A., Kopp, M. (2006). A WHO Jól-Lét Kérdőív Rövidített (WBI-5) Magyar Változatának Validálása a Hungarostudy 2002 Országos Lakossági Egészségfelmérés alapján. Mentálhigiéné és Pszichoszomatika 7(3), 247-255.

https://doi.org/10.1556/mental.7.2006.3.8

[27] Taylor, S., Landry, C. A., Paluszek, M. M., Fergus, T. A., McKay, D., \& Asmundson, G. J. G. (2020). Development and initial validation of the COVID Stress Scales. Journal of Anxiety Disorders, 72, 102232. https://doi.org/10.1016/j.janxdis.2020.102232

[28] Ursin, H., \& Eriksen, H. R. (2004). The cognitive activation theory of stress. Psychoneuroendocrinology, 29(5), 567-592. https://doi.org/10.1016/s03064530(03)00091-x

[29] Xiong, J., Lipsitz, O., Nasri, F., Lui, L. M. W., Gill, H., Phan, L., ... McIntyre, R. S. (2020). Impact of COVID-19 Pandemic on Mental Health in the General Population: A Systematic Review. Journal of Affective Disorders. 277: 55-64. doi: $10.1016 /$ j.jad.2020.08.001 